Brit. J. industr. Med., 1955, 12, 279.

\title{
COAL-MINERS' PNEUMOCONIOSIS IN FOUR COLLIERIES IN COUNTY DURHAM
}

\author{
BY \\ R. I. McCALLUM and R. C. BROWNE \\ with statistical assistance from $\mathrm{H}$. CAMPBELL \\ From the Nuffield Department of Industrial Health, King's College, Newcastle upon Tyne, University of Durham
}

(RECEIVED FOR PUBLICATION NOVEMBER 4, 1954)

\begin{abstract}
Aims of the Investigation
Clinical experience (Browne, Beck, and McCallum, 1949) and rising certification figures by the Pneumoconiosis Medical Board show that there is a pneumoconiosis problem amongst Durham coalminers. Moreover, a study of large films, taken following routine mass miniature radiography (M.M.R.) at eight Durham pits (McCallum, 1952), suggested that at least 3 to $6 \%$ of miners at these pits had well marked radiological signs of pneumoconiosis. This was a crude estimate, because the number of volunteers at each pit was never more than $61 \%$ of the total number of men employed, and the composition of the sample not radiographed was unknown. It may be that those men not radiographed had a higher proportion of disease than those who were. Furthermore, only full-size chest films taken of the men whose miniature appeared abnormal were studied; an unknown number of cases in the early categories of pneumoconiosis were missed in the viewing of the miniature films. A survey to measure the prevalence of pneumoconiosis in a number of collieries in County Durham therefore seemed necessary.

This paper describes planned surveys in four representative Durham pits in 1950-51, in which an attempt was made to radiograph every man employed above or below ground with a full-size chest film (12 in. $\times 15$ in.). It must be emphasized that only the radiological appearances of pneumoconiosis are dealt with here, and that no detailed attempt is made to relate these to symptoms nor to estimate how much respiratory disability is the result of the changes described. An attempt has, however, been made to relate the radiological picture to whether a man has to change his job to one which is lighter.
\end{abstract}

\section{Methods}

Choice of Pits. - There were several considerations in the choice of suitable pits for these surveys. To take a random sample consisting of many complete collieries in the county is not practicable, since it would produce an impossibly large number of men to be radiographed. It was essential that the collieries should be characteristic of the whole coalfield as far as possible, and that geographical position and degree of mechanization should be taken into account. The coal-mines should not be too big, as the mobile $x$-ray unit which was to be used for this work was only available for short periods, and there had to be a reasonable prospect of examining every man and following up those who did not come forward. Suitable accommodation near the pit head was necessary, and, in order to ensure that there would be a full attendance and that most or all of the men would have worked at the pit for the major part of their working life, a compact community was desirable. Finally, pits which had not previously had a visit from an $x$-ray unit were more likely to give the true prevalence of pneumoconiosis, since many men with this condition would not have already been detected and perhaps advised to change their job, thereby leaving a selected population.

The Collieries Chosen.-Two pits $(\mathrm{L}, \mathrm{M})$ were in the western part of the coalfield and two $(\mathrm{K}, \mathrm{N})$ in the eastern part where the future development of this coalfield largely lies. The coal in the east of County Durham is beneath a thick layer of rock, while that in the west, in the older part of the field, is not so deep and in the past has been more easily obtained.

In size, these mines varied from 862 men to 1,921 men and it was planned to survey them in 
from one to two months each. No previous surveys of this kind had been made and an M.M.R. unit had not visited these pits before, but the number of men from them who had been certified in each year between 1943 and July, 1948, which was before the use of mass radiography in this coalfield, was known (Table 1).

TABLE 1

NO. OF MEN FROM EACH OF FOUR PITS CERTIFIED BY SILICOSIS BOARD FROM 1943 TO JULY, 1948

\begin{tabular}{|c|c|c|c|c|c|c|c|c|}
\hline Pit & $\begin{array}{l}\text { No. of } \\
\text { Men on } \\
\text { Payroll } \\
1950-51\end{array}$ & 1943 & 1944 & 1945 & 1946 & 1947 & $\begin{array}{l}\text { Half } \\
1948\end{array}$ & Total \\
\hline $\begin{array}{l}\mathbf{K} \\
\mathbf{L} \\
\mathbf{M} \\
\mathbf{N}\end{array}$ & $\begin{array}{r}1,638 \\
862 \\
1,302 \\
1,921\end{array}$ & $\frac{-}{5}$ & $\begin{array}{l}2 \\
1 \\
8\end{array}$ & $\frac{1}{-}$ & $\frac{3}{1}$ & $\frac{3}{8}$ & $\frac{1}{15}$ & $\begin{array}{r}10 \\
0 \\
2 \\
50\end{array}$ \\
\hline
\end{tabular}

According to the certification figures Pit N, with 50 cases, was by far the worst, and indeed was a notoriously bad pit as regards pneumoconiosis, while Pit L was apparently free from this trouble. Pits $\mathrm{K}$ and $\mathrm{L}$ were in compact mining communities, but $M$ drew men from villages all round it, " like a clock face" as a union official described it. Pit $\mathbf{N}$ was near a large town and its workers were widely scattered.

Organization of the Surveys.-The surveys were carried out with the cooperation of the North Eastern Regional Hospital Board, who gave permission to use the Durham Mass Miniature Radiography Unit; the National Coal Board with its divisional and area medical officers; and the National Union of Mineworkers (Durham). A system of appointments was arranged for every man on the pay roll, and a fresh appointment was sent at the end of each day to those who failed to attend.

The purpose of the survey and the importance of a full turn-out of men were explained at public meetings, and any questions from the men were answered.

Before coming for examination men were given a leaflet on which to enter their occupational history in detail from the time of leaving school. In this way each had an opportunity to think about it and perhaps to set it out more accurately, thus saving time when attending for radiography. The information was then entered on another sheet by the clerks of the $x$-ray unit who were experienced in taking such histories, and who asked for further details of certain jobs or queried obvious errors and omissions.

Radiology.-The chest films were taken, using standard mass miniature radiography equipment, in a van with trailer generator. No miniature films were taken, as these have been found unsatisfactory for this type of work (Fletcher, 1953 ; Cochrane, 1951 ; McCallum, 1952 ; Newell and McCallum, 1954). Radiographs of the highest possible quality were sought and the number of recalls for technical faults was small.

Films were categorized by three experienced observers, using the Pneumoconiosis Research Unit method, which is a quantitative radiological classification into four categories of increasing amounts of simple pneumoconiosis (Categories 1-4) and four of progressive massive fibrosis (P.M.F., categories A-D), (Fletcher, Mann, Davies, Cochrane, Gilson, and Hugh-Jones, 1949). If the two most advanced simple categories ( 3 and 4 ) are combined into a single category 3 , this classification then corresponds to the proposed International Classification of Pneumoconiosis (Cochrane, Davies, and Fletcher, 1951 ; International Labour Office, 1953). Each observer categorized the films on his own and without prior knowledge of any readings already made by other observers or of the occupational history. This allowed each individual to read at his own speed without the influence of the opinion of other, and perhaps stronger, personalities than his own, a possible disadvantage where combined readings are made.

The final category was determined as follows : if all, or two out of the three, readings agreed, then this was the final category; if all the readings were different, but were consecutive, then the mean reading was the final category; when they were all different but not consecutive, further readings were made by two of the observers working separately, up to a total of seven readings, and either the simple majority reading or the mean to the nearest whole number of these readings was made the final category. The number of films which it was necessary to read more than three times was only seven in Pit K, 12 in L, seven in M, and 39 in N.

Follow-up of Non-attenders. - A social worker from the Department of Industrial Health paid a visit to every man on the pay roll of each colliery who did not come for a radiograph. A personal appeal and explanation was made, together with an offer of $x$-ray examination either at Newcastle or elsewhere. If the refusal was point-blank or there were good reasons for not attending, such as illness, at least some information was obtained about the man and his occupational history, so that it was possible to assess from this the amount of exposure to dust that he was likely to have had. For example, if he was a young man with no facework he would be unlikely to have pneumoconiosis. On the other 
hand, a man of 55 with 30 years of facework might be more likely to have it.

\section{Results}

The Response of the Men.-Eighty-nine per cent. of 5,723 coal workers above and below ground at the four Durham collieries were radiographed (Table 2).

T.ABLE 2

NO.* AND PERCENTAGE OF MEN AT EACH COLLIERY RADIOGRAPHED AT THE SURVEYS

\begin{tabular}{|c|c|c|c|c|}
\hline \multirow{2}{*}{ Colliery } & \multirow{2}{*}{$\begin{array}{l}\text { Total No. of } \\
\text { Men from } \\
\text { Pay Record }\end{array}$} & \multicolumn{2}{|c|}{ Men Radiographed } & \multirow{2}{*}{$\begin{array}{l}\text { Men not } \\
\text { Radio- } \\
\text { graphed }\end{array}$} \\
\hline & & No. & $\%$ & \\
\hline $\begin{array}{l}\mathbf{K} \\
\mathbf{L} \\
\mathbf{M} \\
\mathbf{N}\end{array}$ & $\begin{array}{r}1,638 \\
862 \\
1,302 \\
1,921\end{array}$ & $\begin{array}{r}1,539 \\
803 \\
1,180 \\
1,596\end{array}$ & $\begin{array}{l}94.0 \\
93.2 \\
90.6 \\
83.1\end{array}$ & $\begin{array}{r}99 \\
59 \\
122 \\
325\end{array}$ \\
\hline Total & 5,723 & 5,118 & $89 \cdot 4$ & 605 \\
\hline
\end{tabular}

* The total number of men employed at the colliery was obtained from the pay records at the time of the survey.

The highest proportion of men attended at the first two collieries visited, which were the most compact communities and where the $x$-ray unit was nearest the shaft top. The lowest percentage $(83 \%)$ was at the fourth colliery, where conditions for the work were less satisfactory and the unit some distance away from the shaft.

Prevalence.-The radiological diagnosis of cases of pneumoconiosis, all categories, in these pits varied from 30 to $35 \%$ of the men, with an average of $32 \%$ (Table 3 ). If the faceworkers only are

TABLE 3

PERCENTAGE OF EXAMINED MEN WITH PNEUMOCONIOSIS IN EACH COLLIERY BY CATEGORIES

\begin{tabular}{|c|c|c|c|c|c|c|c|c|}
\hline \multirow{3}{*}{ Category } & \multicolumn{8}{|c|}{ Colliery } \\
\hline & \multicolumn{2}{|c|}{ K } & \multicolumn{2}{|c|}{ L } & \multicolumn{2}{|c|}{$\mathbf{M}$} & \multicolumn{2}{|c|}{$\mathbf{N}$} \\
\hline & No. & $\%$ & No. & $\%$ & No. & $\%$ & No. & $\%$ \\
\hline $\begin{array}{c}1 \\
2 \\
3 \text { and } 4 \\
\text { P.M.F. }\end{array}$ & $\begin{array}{r}129 \\
175 \\
119 \\
43\end{array}$ & $\begin{array}{r}8.4 \\
11.4 \\
7.7 \\
2.8\end{array}$ & $\begin{array}{r}88 \\
76 \\
68 \\
9\end{array}$ & $\begin{array}{r}10.9 \\
9.5 \\
8.5 \\
1.1\end{array}$ & $\begin{array}{r}156 \\
120 \\
79 \\
15\end{array}$ & $\begin{array}{r}13 \cdot 2 \\
10 \cdot 2 \\
6.7 \\
1.3\end{array}$ & $\begin{array}{r}156 \\
185 \\
182 \\
43\end{array}$ & $\begin{array}{r}9.8 \\
11.6 \\
11.4 \\
2.7\end{array}$ \\
\hline Total & 466 & $30 \cdot 3$ & 241 & $30 \cdot 0$ & 370 & 31.4 & 566 & $\overline{35 \cdot 5}$ \\
\hline
\end{tabular}

considered, then the average prevalence of pneumoconiosis is $39 \%$ at these pits.

In each colliery the proportion of films placed in Categories 1 and 2, between which there is probably most disagreement, does not differ greatly, and it is noteworthy that only a little over $2 \%$ of all the men had progressive massive fibrosis with which most disability is associated (Cochrane, Fletcher, Gilson, and Hugh-Jones, 1951).

Twenty-four office workers and other non-mining employees were also included, five each in collieries
$K, L$, and $M$, and nine in colliery $N$, so that the results are very slightly diluted by these men not at risk. On the other hand, they provided a useful control of the validity of the radiology. These men, whose average age was 36 years with a range of $15 \frac{1}{2}$ to 65 years, were all placed in Category 0 although their occupational histories were not known by the viewers.

The overall results of the surveys in each pit are strikingly similar, especially in Pits $\mathrm{K}, \mathrm{L}$, and $\mathrm{M}$. Pit $\mathrm{N}$ has more men in Category 3, which may be the result of much dustier conditions, but this pit had relatively more older men with longer exposure to dusty conditions. In age groups 36 to 45 years and 46 to 55 years a third of all the men were in Colliery $\mathrm{N}$ (Table 4). If only the very obvious categories of

TABLE 4

NO. AND PERCENTAGE OF ALL MEN RADIOGRAPHED BY COLLIERY AND AGE

\begin{tabular}{|c|c|c|c|c|c|c|c|c|c|c|}
\hline \multirow{3}{*}{ Age } & \multicolumn{10}{|c|}{ Colliery } \\
\hline & \multicolumn{2}{|c|}{ K } & \multicolumn{2}{|c|}{$\mathrm{L}$} & \multicolumn{2}{|c|}{$\mathbf{M}$} & \multicolumn{2}{|c|}{$\mathbf{N}$} & \multicolumn{2}{|c|}{ Total } \\
\hline & No. & $\%$ & No. & $\%$ & No. & $\%$ & No. & $\%$ & No. & $\%$ \\
\hline $\begin{array}{l}15-25 \\
26-35 \\
36-45 \\
46-55 \\
56+\end{array}$ & $\begin{array}{l}333 \\
396 \\
337 \\
287 \\
186\end{array}$ & $\begin{array}{l}35.9 \\
32.8 \\
26.7 \\
27.5 \\
27.4\end{array}$ & $\begin{array}{l}181 \\
165 \\
196 \\
137 \\
124\end{array}$ & \begin{tabular}{l|}
19.5 \\
13.7 \\
15.5 \\
13.1 \\
18.2
\end{tabular} & $\begin{array}{l}183 \\
243 \\
304 \\
274 \\
176\end{array}$ & $\begin{array}{l}19 \cdot 7 \\
20 \cdot 1 \\
24 \cdot 1 \\
26 \cdot 3 \\
25 \cdot 9\end{array}$ & \begin{tabular}{|l|}
230 \\
403 \\
425 \\
344 \\
194
\end{tabular} & $\begin{array}{l}24.8 \\
33.4 \\
33.7 \\
33.0 \\
28.5\end{array}$ & $\begin{array}{r}927 \\
1207 \\
1262 \\
1042 \\
680\end{array}$ & $\begin{array}{r}99.9 \\
100.0 \\
100.0 \\
99.9 \\
100.0\end{array}$ \\
\hline & 1,539 & $30 \cdot 1$ & 803 & $15 \cdot 7$ & 1,180 & $23 \cdot 1$ & 1,596 & 31.2 & 5,118 & $100 \cdot 1$ \\
\hline
\end{tabular}

pneumoconiosis are considered (Category 3 upwards), $11 \%$ of men show radiological changes, a figure approximately double that previously reported from this coalfield.

The amount of progressive massive fibrosis is also very similar in all four pits. The observer error in separating these categories from the simple ones is relatively small, but as they are the most easily recognized and cause most disability, the numbers have probably suffered most from withdrawals due to ill-health, death, or certification.

Nearly all the faceworkers had done at least three-quarters of their facework at the same pits, and it can reasonably be assumed that the lung

TABLE 5

PROPORTION OF FACEWORKERS' YEARS AT THE FACE SPENT AT THEIR PRESENT COLLIERY

\begin{tabular}{|c|c|c|c|c|}
\hline \multirow[b]{2}{*}{ Category } & \multicolumn{4}{|c|}{ Colliery } \\
\hline & $\underset{(\%)}{K}$ & $\begin{array}{c}\mathrm{L} \\
(\%)\end{array}$ & $\underset{(\%)}{M}$ & $\begin{array}{c}N \\
(\%)\end{array}$ \\
\hline \multirow[t]{2}{*}{$\begin{array}{c}0 \\
1 \\
2 \\
3 \text { and } 4 \\
\text { P.M.F. }\end{array}$} & $\begin{array}{l}93 \cdot 2 \\
93 \cdot 5 \\
95 \cdot 8 \\
98 \cdot 1 \\
97 \cdot 7\end{array}$ & $\begin{array}{l}76 \cdot 1 \\
78 \cdot 3 \\
81 \cdot 6 \\
81.4 \\
73 \cdot 6\end{array}$ & $\begin{array}{l}74 \cdot 1 \\
75 \cdot 5 \\
81 \cdot 0 \\
86 \cdot 1 \\
82 \cdot 8\end{array}$ & $\begin{array}{l}86 \cdot 8 \\
85 \cdot 5 \\
88 \cdot 4 \\
89 \cdot 3 \\
88.4\end{array}$ \\
\hline & $95 \cdot 1$ & 78.6 & $77 \cdot 8$ & $87 \cdot 6$ \\
\hline
\end{tabular}


changes found were the result of the dust in the pits in which they were working when radiographed (Table 5).

Most of the time which the men who were radiographed had spent elsewhere was frequently in a mine or mines in the same area.

Withdrawal from Facework.-Some evidence of the relation between the radiological findings and disability from pneumoconiosis was obtained from an analysis of the withdrawals from facework to non-facework, as shown by the occupational histories. In this report "facework" refers to certain well defined jobs which involve regular exposure to high concentration of mixed dust at or - near the coal face and it includes all the men radiographed who have worked for six months or more as a hewer (hand or pneumatic), coal cutter, stoneman, filler, deputy, or shotfirer. Men who had worked for less than six months at these jobs or who had never done them at any time were classed as non-faceworkers. In each colliery the findings were much the same, the percentage of withdrawals increasing with age. When the age of withdrawal of men from facework is set out by categories, it is evident that an increase in simple category is not accompanied by a corresponding increase in the change from facework to non-facework, but that in the group with P.M.F. the percentage of withdrawals rises greatly (Table 6). No information is available of the number of men who have left these collieries altogether, either from age and all causes of ill-health or because no light work was available for them, but there is, in recent years, a tendency for certified pneumoconiosis cases to remain on, as they are usually considered first for light jobs, and this would affect men at the collieries in all categories over 2 . In simple pneumoconiosis increasing

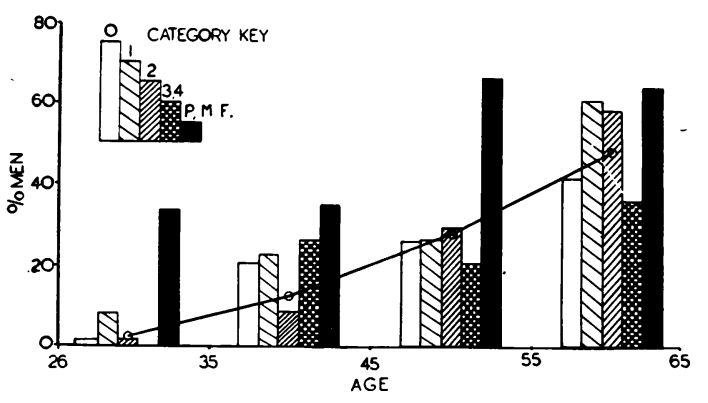

FIG. 1.-The proportion of men who give up coal-facework by age and category. The curve links the averages for each age group.

age rather than increasing category seems to be correlated with change to lighter work and withdrawal from the coal face (Fig. 1). Even in radiological categories 3 and 4 for the two age groups over 46 there were not more withdrawals than in Category 0 for the same age groups. But for all categories there is increasing withdrawal from facework as age rises. In the P.M.F. categories, however, for each age group a higher proportion of men withdraw from the coal face than in any simple category, and the proportion of withdrawals increases by age also, being $33.3 \%$ in the decade 26 to 35 , but $63.6 \%$ at 56 to 65 . The advice given to the certified men is an unknown variable, but it is likely that, especially in the complicated categories, a number of men were advised to leave the coal face because of the appearance of their radiographs rather than because they were disabled. Furthermore, progression from simple pneumoconiosis to P.M.F. may occur whether men withdraw from dusty work or remain in it (Davies, Fletcher, Mann, and Stewart, 1949), although recent work suggests that the attack rate of P.M.F is greater in those men with continuing dust exposure (Cochrane, personal

TABLE 6

TOTAL FACEWORKERS, OR FORMER FACEWORKERS, BY AGE AND CATEGORY, SHOWING NUMBER AND PERCENTAGE WITHDRAWN FROM FACEWORK FOR AT LEAST SIX MONTHS AT TIME OF SURVEY BUT STILL EMPLOYED AT THE COLLIERY*

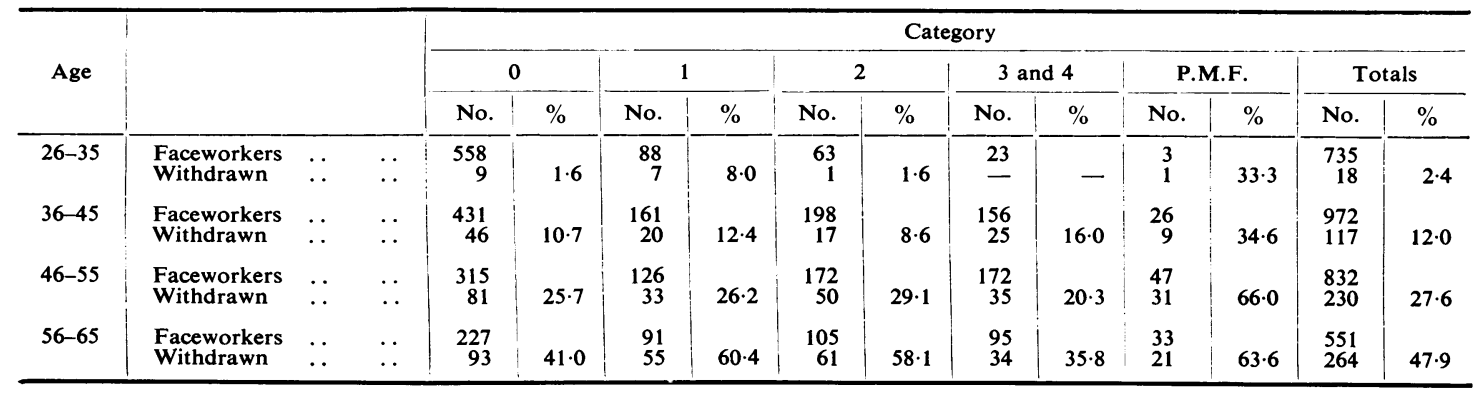

* No information is available concerning men who have left the pit altogether or have been unable to get work at the pit. 
TABLE 7

NO. AND PERCENTAGE OF MEN IN EACH RADIOLOGICAL CATEGORY BY AGE *

\begin{tabular}{|c|c|c|c|c|c|c|c|c|c|c|c|c|c|}
\hline \multirow{3}{*}{$\begin{array}{l}\text { Age in } \\
\text { Years }\end{array}$} & \multicolumn{10}{|c|}{ Radiological Category } & \multirow{3}{*}{ Total } & \multirow{3}{*}{$\begin{array}{c}\% \text { in } \\
\text { Category } \\
1 \text { and } \\
\text { Over }\end{array}$} & \multirow{3}{*}{$\begin{array}{c}\% \text { in } \\
\text { Category } \\
2 \text { and } \\
\text { Over }\end{array}$} \\
\hline & \multicolumn{2}{|c|}{0} & \multicolumn{2}{|c|}{1} & \multicolumn{2}{|c|}{2} & \multicolumn{2}{|c|}{3 and 4} & \multicolumn{2}{|c|}{ P.M.F. } & & & \\
\hline & No. & $\%$ & No. & $\%$ & No. & $\%$ & No. & $\%$ & No. & $\%$ & & & \\
\hline $\begin{array}{l}15-25 \\
26-35 \\
36-45 \\
46-55 \\
56+\end{array}$ & $\begin{array}{r}909 \\
1,018 \\
701 \\
507 \\
340\end{array}$ & $\begin{array}{l}98 \cdot 1 \\
84 \cdot 3 \\
55 \cdot 5 \\
48 \cdot 7 \\
50 \cdot 0\end{array}$ & $\begin{array}{r}17 \\
98 \\
173 \\
139 \\
102\end{array}$ & $\begin{array}{r}1.8 \\
8.1 \\
13.7 \\
13.3 \\
15.0\end{array}$ & $\begin{array}{r}1 \\
65 \\
204 \\
177 \\
109\end{array}$ & $\begin{array}{r}0.1 \\
5.4 \\
16.2 \\
17.0 \\
16.0\end{array}$ & $\begin{array}{r}\overline{23} \\
157 \\
172 \\
96\end{array}$ & $\begin{array}{r}1 \overline{1} \cdot 9 \\
12 \cdot 4 \\
16 \cdot 5 \\
14 \cdot 1\end{array}$ & $\begin{array}{r}-3 \\
27 \\
47 \\
33\end{array}$ & $\begin{array}{l}\overline{0.2} \\
2 \cdot 1 \\
4 \cdot 5 \\
4.9\end{array}$ & $\begin{array}{r}927 \\
1,207 \\
1,262 \\
1,042 \\
680\end{array}$ & $\begin{array}{r}1.9 \\
15.7 \\
44.5 \\
51 \cdot 3 \\
50.0\end{array}$ & $\begin{array}{r}0 \cdot 1 \\
7 \cdot 5 \\
30 \cdot 7 \\
38 \cdot 0 \\
35 \cdot 0\end{array}$ \\
\hline Total & 3,475 & $67 \cdot 9$ & 529 & $10 \cdot 3$ & 556 & $10 \cdot 9$ & 448 & $8 \cdot 8$ & 110 & $2 \cdot 1$ & 5,118 & $32 \cdot 1$ & $21 \cdot 8$ \\
\hline
\end{tabular}

communication), so that the number of men with P.M.F. amongst those who have withdrawn from facework may be augmented to some extent by the development of P.M.F. in men who left facework with simple pneumoconiosis.

Increasing Age.-If the men are grouped by age and radiological category in the Pneumoconiosis Research Unit classification (Fletcher and others, 1949), it is found that as age increases the proportion of men in each category of pneumoconiosis increases until 36 to 45 and then stabilizes (Table 7).

Between 26 and 35 years nearly $16 \%$ of the men have pneumoconiosis of Category 1 and over, or if Category 1 is excluded, $7.5 \%$ of the men. Between 36 and 45 years of age the proportion rises to $44.5 \%$ for all categories, or nearly $31 \%$ without Category 1 , so that whether Category 1 or 2 is taken as the lowest recognizable level the sharp increase over the

TABLE 8

MEN WITH PNEUMOCONIOSIS (CATEGORY 1 AND ABOVE) IN EACH COLLIERY BY AGE

\begin{tabular}{|c|c|c|c|c|c|c|c|c|c|c|}
\hline \multirow{3}{*}{ Age } & \multicolumn{10}{|c|}{ Colliery } \\
\hline & \multicolumn{2}{|c|}{$\mathbf{K}$} & \multicolumn{2}{|c|}{$\mathbf{L}$} & \multicolumn{2}{|c|}{$\mathbf{M}$} & \multicolumn{2}{|c|}{$\mathbf{N}$} & \multicolumn{2}{|c|}{ Total } \\
\hline & No. & $\%$ & No. & $\%$ & No. & $\%$ & No. & $\%$ & No. & $\%$ \\
\hline $\begin{array}{l}15-25 \\
26-35 \\
36-45 \\
46-55 \\
56+\end{array}$ & $\begin{array}{r}6 \\
69 \\
158 \\
150 \\
83\end{array}$ & $\begin{array}{r}2 \\
17 \\
47 \\
52 \\
45\end{array}$ & $\begin{array}{r}6 \\
24 \\
77 \\
66 \\
68\end{array}$ & $\begin{array}{r}3 \\
15 \\
39 \\
48 \\
55\end{array}$ & $\begin{array}{r}4 \\
26 \\
119 \\
129 \\
92\end{array}$ & $\begin{array}{r}2 \\
11 \\
39 \\
47 \\
52\end{array}$ & $\begin{array}{r}2 \\
70 \\
207 \\
190 \\
97\end{array}$ & $\begin{array}{r}1 \\
17 \\
49 \\
55 \\
50\end{array}$ & $\begin{array}{r}18 \\
189 \\
561 \\
535 \\
340\end{array}$ & $\begin{array}{r}1.9 \\
15.7 \\
44.5 \\
51.3 \\
50.0\end{array}$ \\
\hline
\end{tabular}

age of 35 years remains. The same change occurs quite distinctly in each colliery (Table 8), and further emphasizes the marked similarity in the results of the surveys in these four geographically widely separated pits in Durham.

After 35 years of age the proportion of men with pneumoconiosis in each 10-year group remains much the same until the age of 55 when there is a slight fall, but the number of men in this group is only about half of those in each of the preceding three groups.

Years at Facework.-The men have been divided into those who have done facework and those who have not, on the basis of their occupational histories, rather than making a distinction between surface and underground workers. Underground workers may be at some distance from the face and their dust exposure low or intermittent, while many men in surface jobs have spent a period at facework and have changed to the surface because of disability from a variety of causes, including pneumoconiosis. What is important in the occupational history is not what a man is doing when the radiograph is taken but what the pattern of his history has been for the whole of its length.

In Table 9 and Fig. 2 the men are grouped by radiological categories and number of years spent at facework. It is notable that only $1 \%$ of the non-

TABLE 9

NO. AND PERCENTAGE OF MEN IN EACH RADIOLOGICAL CATEGORY BY YEARS AT FACEWORK*

\begin{tabular}{|c|c|c|c|c|c|c|c|c|c|c|c|c|c|}
\hline \multirow{3}{*}{$\begin{array}{l}\text { No. of } \\
\text { Years } \\
\text { at } \\
\text { Face }\end{array}$} & & & & & \multicolumn{6}{|c|}{ Radiological Category } & \multirow{3}{*}{ Total } & \multirow{3}{*}{$\begin{array}{c}\% \text { in } \\
\text { Category } \\
1 \text { and } \\
\text { Over }\end{array}$} & \multirow{3}{*}{$\begin{array}{c}\% \text { in } \\
\text { Category } \\
2 \text { and } \\
\text { Over }\end{array}$} \\
\hline & \multicolumn{2}{|c|}{0} & \multicolumn{2}{|c|}{1} & \multicolumn{2}{|c|}{2} & \multicolumn{2}{|c|}{3 and 4} & \multicolumn{2}{|c|}{ P.M.F. } & & & \\
\hline & No. & $\%$ & No. & $\%$ & No. & $\%$ & No. & $\%$ & No. & $\%$ & & & \\
\hline $\begin{array}{r}0 \\
1-10 \\
11-20 \\
21-30 \\
31+\end{array}$ & $\begin{array}{r}1,811 \\
924 \\
341 \\
237 \\
162\end{array}$ & $\begin{array}{l}96 \cdot 0 \\
75 \cdot 3 \\
40 \cdot 4 \\
34 \cdot 1 \\
34 \cdot 8\end{array}$ & $\begin{array}{r}55 \\
155 \\
145 \\
97 \\
77\end{array}$ & $\begin{array}{r}2.9 \\
12.6 \\
17.2 \\
14.0 \\
16.5\end{array}$ & $\begin{array}{r}17 \\
100 \\
185 \\
153 \\
101\end{array}$ & $\begin{array}{r}0.9 \\
8 \cdot 1 \\
21.9 \\
22.0 \\
21.7\end{array}$ & $\begin{array}{r}2 \\
43 \\
139 \\
170 \\
94\end{array}$ & $\begin{array}{r}0.1 \\
3.5 \\
16.4 \\
24.5 \\
20.2\end{array}$ & $\begin{array}{r}1 \\
5 \\
35 \\
37 \\
32\end{array}$ & $\begin{array}{l}0 \cdot 1 \\
0 \cdot 4 \\
4 \cdot 1 \\
5 \cdot 3 \\
6 \cdot 9\end{array}$ & $\begin{array}{r}1,886 \\
1,227 \\
845 \\
694 \\
466\end{array}$ & $\begin{array}{r}4.0 \\
24.7 \\
59 \cdot 6 \\
65.9 \\
65 \cdot 2\end{array}$ & $\begin{array}{r}1 \cdot 1 \\
12.1 \\
42.5 \\
51.9 \\
48.7\end{array}$ \\
\hline Total & 3,475 & & 529 & & 556 & & 448 & & 110 & & 5,118 & & \\
\hline
\end{tabular}

* Categories 3 and 4 have been combined, also all categories of P.M.F. 


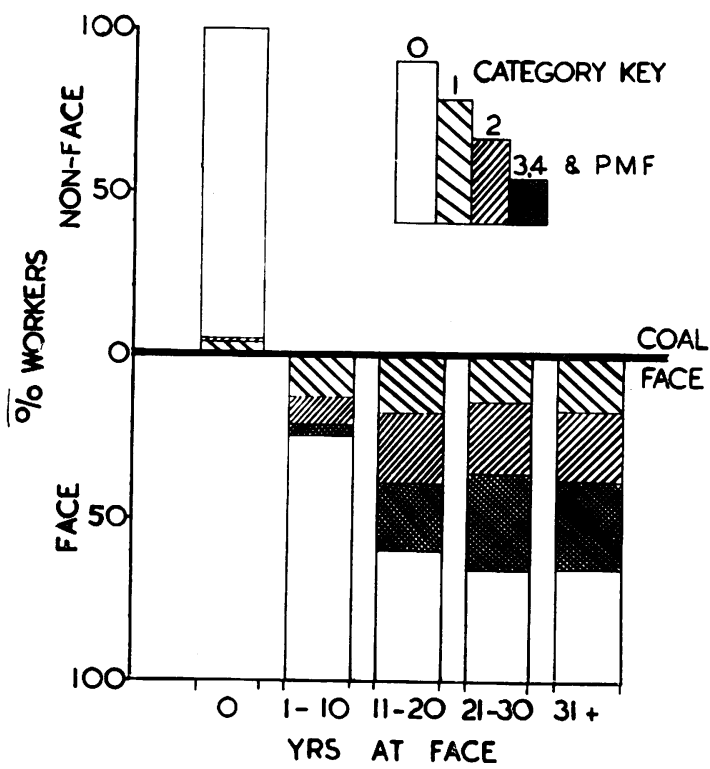

FIG. 2.-The proportion of men with pneumoconiosis related to years at the coal face.

faceworkers shows changes of Category 2 or more and that there was only one man with P.M.F.

This small proportion of non-faceworkers with early pneumoconiosis is probably made up of men whose dust exposure has nevertheless been high, or men with a high susceptibility to dust retention. Of the 75 non-faceworkers with pneumoconiosis, 46 worked at the same time as datal workers (labouring underground) or on haulage work underground, often for long periods. Of 29 men who had never worked underground at all, 11 had worked as coal screeners and nine as blacksmiths at some time.

After one to 10 years at the face $12 \%$ of the faceworkers are in Category 2 or more, but this figure is nearly quadrupled after 11 to 20 years at the face. About 10 years at facework appears to be a crucial point, after which the main effect of the dust becomes marked, corresponding to the rise after the age of 35 years (Table 7). The proportion of men in each category tends to remain at the same level after a certain period of time ; for example, in Category 1 the proportion reaches about $16 \%$ after eight years' facework, in Category 2 it reaches $22 \%$ after 13 years, and after about 23 years Category 3 and the complicated categories together remain at $29 \%$ of the men.

The most striking feature of Table 9 is that after 20 years at the face half the men have radiological pneumoconiosis of Category 2 or more, and nearly $30 \%$ have well marked changes of Category 3 and/ or progressive massive fibrosis. After about 30 years at the face there is a slight drop in the proportion of men with pneumoconiosis, but the numbers are smaller though the difference is not so great as in the men over 55 in Table 7.

When the collieries are considered separately the results in each are again remarkably similar (Table 10).

TABLE 10

PERCENTAGE OF PNEUMOCONIOSIS (CATEGORY 1 AND ABOVE) BY COLLIERIES

\begin{tabular}{c|r|r|r|r|r}
\hline $\begin{array}{c}\text { Years at } \\
\text { Face }\end{array}$ & \multicolumn{4}{|c|}{ Colliery } & Average \\
\hline 0 & $\mathrm{~K}$ & \multicolumn{1}{|c|}{$\mathrm{L}$} & $\mathrm{M}$ & $\mathrm{N}$ & \\
\hline $1-10$ & 3 & 5 & 6 & 3 & $4 \cdot 0$ \\
$11-20$ & 42 & 21 & 16 & 26 & $24 \cdot 7$ \\
$21-30$ & 71 & 62 & 56 & 62 & $59 \cdot 6$ \\
$31-$ & 61 & 66 & 65 & 65 & 65.9 \\
\hline
\end{tabular}

Age and Facework Together.-The effect of age and facework together is shown in Table 11, in which the data for Category 2 or more are combined. If the apparent effect of age alone upon the appearances of pneumoconiosis be considered, it can be seen that for men who have never been on the coal face there is a rise from $0.4 \%$ at ages 26 to 35 to $2.8 \% 10$ years later, but the proportion of pneumoconiotics then remains constant. For the men who have spent one to 10 years at the coal face there is a rise with age to $19 \%$ at 36 to 45 years, and then a gradual fall. At 11 to 20 face-years there is a rise which is about twice as steep from age 26 to 45 , followed by a steeper fall. For the next two decennial

TABLE 11

MEN BY AGE AND YEARS OF FACEWORK WITH PNEUMOCONIOSIS OF CATEGORY 2 OR MORE

\begin{tabular}{|c|c|c|c|c|c|c|c|c|c|c|c|c|}
\hline \multirow{3}{*}{ Age } & \multicolumn{12}{|c|}{ Years at the Face } \\
\hline & \multicolumn{2}{|c|}{0} & \multicolumn{2}{|c|}{$1-10$} & \multicolumn{2}{|c|}{$11-20$} & \multicolumn{2}{|c|}{$21-30$} & \multicolumn{2}{|c|}{31 and Over } & \multicolumn{2}{|c|}{ Average } \\
\hline & No. & $\%$ & No. & $\%$ & No. & $\%$ & No. & $\%$ & No. & $\%$ & No. & $\%$ \\
\hline \multirow[t]{2}{*}{$\begin{array}{l}15-25 \\
26-35 \\
36-45 \\
46-55 \\
56+\end{array}$} & $\begin{array}{l}0 \\
2 \\
8 \\
6 \\
4\end{array}$ & $\begin{array}{l}\overline{0.4} \\
2.8 \\
2.8 \\
3 \cdot 1\end{array}$ & $\begin{array}{r}1 \\
72 \\
58 \\
12 \\
5\end{array}$ & $\begin{array}{r}0.7 \\
10.7 \\
19 \cdot 0 \\
16.4 \\
12.8\end{array}$ & $\begin{array}{r}-17 \\
244 \\
81 \\
17\end{array}$ & $\begin{array}{l}\overline{26 \cdot 2} \\
46 \cdot 5 \\
38.4 \\
37 \cdot 8\end{array}$ & $\begin{array}{r}- \\
\overline{78} \\
232 \\
50\end{array}$ & $\begin{array}{l}- \\
54 \cdot 6 \\
55 \cdot 0 \\
39 \cdot 4\end{array}$ & $\begin{array}{c}\bar{Z} \\
\overline{65} \\
162\end{array}$ & $\begin{array}{l}- \\
5 \overline{51.6} \\
47.6\end{array}$ & $\begin{array}{r}1 \\
91 \\
388 \\
396 \\
238\end{array}$ & $\begin{array}{r}0 \cdot 1 \\
7 \cdot 5 \\
30 \cdot 7 \\
38 \cdot 0 \\
35 \cdot 0\end{array}$ \\
\hline & 20 & $1 \cdot 1$ & 148 & $12 \cdot 1$ & 359 & $42 \cdot 5$ & 360 & $51 \cdot 9$ & 227 & $48 \cdot 7$ & 1,114 & $21 \cdot 8$ \\
\hline
\end{tabular}


periods at the face there is a fall in the proportion of pneumoconiotics as they become older.

But in considering the time spent at the coal face, there appears to be a rise in the proportion of affected men with increasing face experience which, on the whole, tends to stabilize after 20 years. About $1 \%$ of the men with no face experience, $12 \%$ with one to 10 years' exposure, $42 \%$ with 11 to 20 years', $52 \%$ with 21 to 30 years', and finally $49 \%$ with over 31 years' exposure, had pneumoconiosis.

Pulmonary Tuberculosis.-In diagnosing pulmonary tuberculosis the suggestion made in the notes accompanying the P.R.U. set of standard films was in general followed: shadows which might be tuberculous were diagnosed as such in films with pneumoconiosis of less than Category 2, while in films with Category 2 or 3 pneumoconiosis in which any localized shadow suggested tuberculosis or early massive fibrosis, Category A was diagnosed unless the shadow was characteristic of healed inactive tuberculosis. Men with clinically significant pulmonary tuberculosis necessitating referral to chest clinics number three, five, and four respectively in collieries $\mathrm{K}, \mathrm{L}$, and $\mathrm{M}$, but in colliery $\mathrm{N} 22$ men were referred to chest clinics. This is approximately 3 per 1,000 in the first three pits taken together, and 11 per 1,000 in pit $\mathrm{N}$.

The proportion of men with healed pulmonary tuberculosis (excluding primary complex) was also much higher in colliery $\mathrm{N}$ which had $12.7 \%$ compared with an average of $1.7 \%$ for the other three (Table 12).

TABLE 12

MEN SHOWING RADIOLOGICAL EVIDENCE OF HEALED PULMONARY TUBERCULOSIS (EXCEPT PRIMARY COMPLEX)

\begin{tabular}{|c|c|c|c|c|c|c|c|c|}
\hline \multirow{3}{*}{$\begin{array}{l}\text { Age in } \\
\text { Years }\end{array}$} & & & \multicolumn{4}{|c|}{ Colliery } & & \\
\hline & \multicolumn{2}{|c|}{$\mathrm{K}$} & \multicolumn{2}{|c|}{ L } & \multicolumn{2}{|c|}{$\mathbf{M}$} & \multicolumn{2}{|c|}{$\mathbf{N}$} \\
\hline & No. & $\%$ & No. & $o_{0}$ & No. & $\%$ & No. & $\%$ \\
\hline \multirow[t]{2}{*}{$\begin{array}{l}16-25 \\
26-35 \\
36-45 \\
46-55 \\
56-65\end{array}$} & $\begin{array}{l}1 \\
7 \\
2 \\
7 \\
3\end{array}$ & $\begin{array}{l}0.3 \\
1.7 \\
0.6 \\
2.4 \\
1.6\end{array}$ & $\begin{array}{l}\frac{1}{1} \\
1 \\
2\end{array}$ & $\begin{array}{l}0.6 \\
0.5 \\
0.8 \\
1.6\end{array}$ & $\begin{array}{r}3 \\
1 \\
10 \\
11 \\
15\end{array}$ & $\begin{array}{l}1 \cdot 6 \\
0.4 \\
3 \cdot 3 \\
4 \cdot 0 \\
8.5\end{array}$ & $\begin{array}{r}3 \\
22 \\
53 \\
63 \\
63\end{array}$ & $\begin{array}{r}1 \cdot 3 \\
5 \cdot 4 \\
12 \cdot 4 \\
18 \cdot 3 \\
32 \cdot 5\end{array}$ \\
\hline & 20 & $1 \cdot 3$ & 5 & $0 \cdot 6$ & 40 & $3 \cdot 3$ & 204 & $12 \cdot 7$ \\
\hline \multicolumn{2}{|c|}{$\begin{array}{l}\text { Standardized } \\
\text { Rates }\end{array}$} & 1.4 & & $0 \cdot 6$ & & $3 \cdot 2$ & & $12 \cdot 6$ \\
\hline
\end{tabular}

The percentage in collieries $\mathrm{L}, \mathrm{M}$, and $\mathrm{N}$ rises with age, being nearly doubled between 46 and 55 years and 56 and 65 years. The figures for P.M.F., assuming that it is essentially simple pneumoconiosis plus tuberculosis, do not reflect the difference betwcen colliery $\mathrm{N}$ and the rest, and it is possible that this is the result of the greater disablement of men with P.M.F. and their withdrawal from pit work.
Non-attenders. - The results of the follow-up of non-attenders are shown in Table 13.

TABLE 13

MEN NOT RADIOGRAPHED BUT VISITED BY A SOCIAL WORKER

\begin{tabular}{|c|c|c|c|c|c|}
\hline \multirow[b]{2}{*}{ Colliery } & \multicolumn{2}{|c|}{ Men Visited } & \multirow{2}{*}{$\begin{array}{l}\text { Already } \\
\text { Certi- } \\
\text { fied }\end{array}$} & \multirow{2}{*}{$\begin{array}{c}\text { Men not } \\
\text { Inter- } \\
\text { viewed } \\
\text { Per- } \\
\text { sonally }\end{array}$} & \multirow[b]{2}{*}{ Total } \\
\hline & $\begin{array}{c}\text { Non- } \\
\text { face- } \\
\text { workers }\end{array}$ & $\begin{array}{c}\text { Face- } \\
\text { workers }\end{array}$ & & & \\
\hline $\begin{array}{l}\mathbf{K} \\
\mathbf{L} \\
\mathbf{M} \\
\mathbf{N}\end{array}$ & $\begin{array}{l}57 \\
33 \\
64 \\
80\end{array}$ & $\begin{array}{l}39 \\
26 \\
46 \\
63\end{array}$ & $\frac{1}{10^{*}}$ & $\frac{2}{12}$ & $\begin{array}{r}99 \\
59 \\
122 \\
325\end{array}$ \\
\hline Total & 234 & 174 & 11 & 186 & 605 \\
\hline $\begin{array}{l}\% \text { of total number } \\
\text { of men on pay- } \\
\text { roll at all col- } \\
\text { lieries }\end{array}$ & $4 \cdot 1$ & 3.0 & $0 \cdot 2$ & $3 \cdot 3$ & 10.6 \\
\hline
\end{tabular}

* One with pulmonary tuberculosis

$+116(68 \%)$ of these men were under 35 years of age ; the majority were surface men.

The information from these visits was very important, in that it served to show what sort of worker had not been examined and how much the non-attendance was likely to influence the validity of the results. Many of the lapsed were young boys, men who had never been employed underground, or men who had worked most of their time away from the coal face in relatively dust-free conditions. A number of men were found to have been radiographed after all, and a few were known cases of pneumoconiosis who did not feel that the survey concerned them. One hundred and seventytwo men could not be traced at Pit N, mainly because they had no addres̄s at the colliery or had left their last address without notifying the colliery of the change. These were mainly surface men and were probably not regularly employed. Only a few men, all at Pit M, were willing to attend for radiology after the visit. Only 3\% were not interviewed personally, but some information about them was obtained from relatives.

The number of non-attenders in each pit who had done facework at any time is not large. The highest number (63) was at Pit $\mathrm{N}$, the largest pit, and the smallest number (26) at Pit L, the smallest pit and the most compact community. From these findings it is reasonable to assume that the men who were examined were practically the total of those exposed to dust, and that the results of the surveys are applicable to the pits as a whole.

The Environment. - A detailed account of the past working conditions in these pits was not obtainable directly, and no dust counts had been done, but it was known that ventilation had been a serious problem in Pit $\mathbf{N}$ in the past. The seams worked 
and the type of coal produced in these pits are mixed, and include both the hard-texture coking coals as well as the softer gas and steam coals, but no conclusions could be drawn about differences in dustiness of the various seams which were worked. In Pits $\mathbf{N}$ and $\mathbf{K}$ bord and pillar work in blind headings was done until quite recently, but the tendency was to change to better ventilated, longwall work. Pit $\mathbf{L}$ was worked by hand hewing until 1927, when pneumatic picks began to be introduced. Some wet cutting was in use in Pit N, but at the time of the survey there was no water infusion.

Mechanization was not introduced at any precise time, but was a gradual and patchy process which started at different times in the different collieries, and even at different times in various districts in the same colliery. It does not even take the same form. For example, in a single colliery one district may be working with unmechanized hand hewing, another may be gradually introducing mechanized pneumatic hewing, and yet another fully mechanized using coal cutters. The important thing is not whether the mine is mechanized but to how much mechanization a man has been exposed during his working life. An assessment of the degree of mechanization to which the men have been exposed is therefore best made from their occupational histories (Table 14).

TABLE 14

PROPORTION OF TIME SPENT IN VARIOUS TYPES OF FACEWORK AT EACH COLLIERY FROM OCCUPATIONAL HISTORIES

\begin{tabular}{|c|c|c|c|c|c|c|c|}
\hline \multirow{3}{*}{\multicolumn{3}{|c|}{ Type of Work }} & \multicolumn{5}{|c|}{$\%$ Years Spent at It } \\
\hline & & & \multicolumn{4}{|c|}{ Colliery } & \multirow{2}{*}{ Total } \\
\hline & & & \multirow[b]{2}{*}{$\begin{array}{c}K \\
22 \\
34 \\
4 \\
26 \\
4 \\
10\end{array}$} & \multirow{2}{*}{$\begin{array}{r}\text { L } \\
38 \\
26 \\
8 \\
2 \\
16 \\
4 \\
6\end{array}$} & \multirow{2}{*}{$\begin{array}{r}\mathbf{M} \\
32 \\
6 \\
2 \\
8 \\
24 \\
20 \\
8\end{array}$} & \multirow{2}{*}{$\begin{array}{r}\mathrm{N} \\
22 \\
16 \\
2 \\
6 \\
30 \\
16 \\
8\end{array}$} & \\
\hline $\begin{array}{l}\text { Hand hewing . } \\
\text { Pneumatic hewing } \\
\text { Hewing, unspecified } \\
\text { Coal cutting } \quad . \\
\text { Stonework } \\
\text { Filling .. } \\
\text { Deputy .. } \quad . .\end{array}$ & $\begin{array}{l}\because \\
\because \\
\because \\
\therefore\end{array}$ & $\begin{array}{l}. \\
\ldots \\
\ldots \\
\ldots \\
\ldots\end{array}$ & & & & & $\begin{array}{r}26 \\
20 \\
2 \\
6 \\
26 \\
12 \\
8\end{array}$ \\
\hline & & & 100 & 100 & 100 & 100 & 100 \\
\hline
\end{tabular}

Twenty-two to $38 \%$ of the miners' time had been spent hand hewing. In Mine $M$ only $6 \%$ of their time had been spent pneumatic hewing, but from 16 to $34 \%$ in the other three mines. Stonework in the rock above or below the coal seam used from 16 to $30 \%$ of their working life, and filling or shovelling coal either into "tubs" or trucks or on to a conveyor belt took from 4 to $20 \%$ of their time. On the whole, about a quarter of the working life up to when the men were radiographed was spent hand hewing and another quarter doing stonework. About one-fifth was spent pneumatic hewing and much smaller amounts of time doing other jobs.

\section{Discussion}

This survey suggests that there may be more simple pneumoconiosis in County Durham than was previously thought. Such evidence as there was from visits of a mass miniature unit to pits (McCallum, 1952) suggested a prevalence of from 3 to $6 \%$, but the survey described here shows that the true prevalence, including all categories, is $32 \%$, or $22 \%$ from Category 2 upwards for the whole pit population.

The pathology of pneumoconiosis of coal-miners appears to be identical in widely different coalfields (Heppleston, 1951), so that these results may be compared with those from other coalfields.

Figures previously published from the Pneumoconiosis Research Unit (Cochrane, 1951) for four pits in England gave prevalence rates for all categories of pneumoconiosis varying from $26.4 \%$ to $61 \cdot 8 \%$, but these referred only to " underground" workers. In the surveys reported here the figures refer to all the workers at the four collieries, including those above ground, but excluding coke workers. Many older men transfer to surface work from the coal face, so that the inclusion of screeners and timber yard men gives a more complete picture than would underground workers only, for chest radiography in pneumoconiosis measures a man's past, but not his present, exposure to dust.

The proportion of men who were radiographed in the (Welsh) Rhondda Fach Scheme (Cochrane, Cox, and Jarman, 1952) was $99 \%$ in four collieries, using a full-time staff and a special unit. In the Durham survey reported here, using a part-time staff and a standard Regional Board mass miniature unit as a mobile large film unit, $89 \%$ of the men in four collieries were radiographed.

In the Rhondda Fach survey about $13 \%$ of miners and ex-miners had progressive massive fibrosis. Our figure was $2 \%$. This bears out an impression gained from the previous investigations in Durham that this type of disease may be more common in South Wales than in the North-East.

It is clear that these Durham collieries have been dusty enough in the past to produce pneumoconiosis, and that if the conditions remain unchanged they will continue to do so in the future. The men with well marked lung changes (Category 2 upwards) have spent a higher proportion of their working lives in these mines than those with normal lungs or with Category 1 changes. Unfortunately, no measurements of dust concentration over the years 


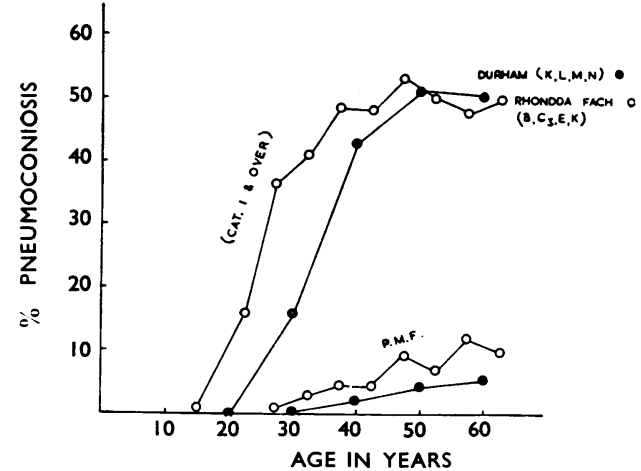

FIG. 3

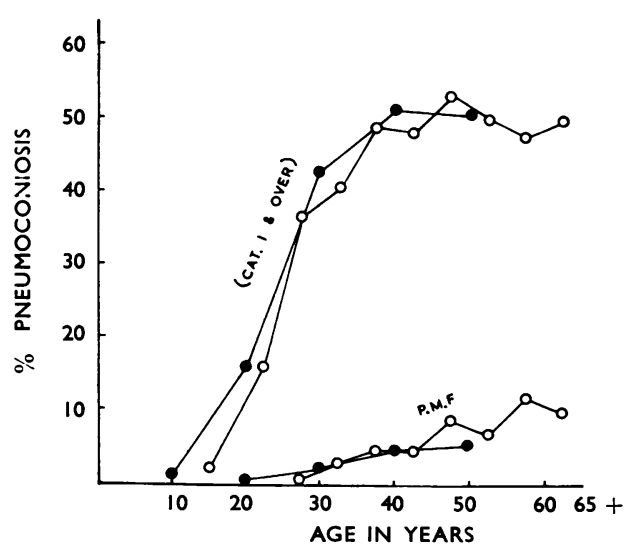

FIG. 4

FIG. 3.-Percentage of pneumoconiosis (Category 1 and over) in four Durham collieries, and four in the Rhondda Fach by years of age. Simple pneumoconiosis and P.M.F. are shown separately. The Rhondda Fach figures refer to all underground workers, the Durham figures to all men who have done more than six months' work at the coal face.

FIG. 4.-The graph for Durham collieries (Fig. 3) has been moved 10 years to the left to show the very close similarity between the two areas.

preceding these surveys exist which can be used to match the radiological results.

In County Durham, men between the ages of 14 and 20 years have usually worked at relatively dustfree jobs on the surface or underground away from the face. In only a few instances have men under 20 years of age already done facework for two or three years. After the age of 20 it is usual for the men to progress through jobs which take them to the face intermittently, such as driving and putting, to actual facework as hewers, cutters, stonemen, etc., if they remain in pit work. It is at this point that heavy exposure to dust probably begins, with the resulting rise in prevalence of pneumoconiosis after the age of 35 years, or after about 10 years at facework.

Cochrane and Gilson (personal communication) compared our results from this survey of four Durham pits with data from four pits in the Rhondda Fach, South Wales. The South Wales figures refer to " all miners working underground" while those from Durham refer to all men with a history of six months or more at facework, that is, men actually hewing or cutting the coal, doing stonework, shifting conveyors, or whose work takes them constantly to and from the face such as putting and driving. When the proportion of men with pneumoconiosis of Category 1 or more is analysed by age (Fig. 3), the similarity between the two groups is very striking when all the variables in radiographic technique, film viewing, and in taking occupational histories are considered. Furthermore, there is a fairly regular eight to 10 years' difference between the two groups, and if the Durham figures are moved 10 years to the left (Fig. 4) there is a remark- able agreement between both simple and complicated pneumoconiosis in the two areas. Cochrane and Gilson point out that on the average the Durham miners went on to the coal face at the age of 20 to 25 years, which is approximately eight to 10 years later than is usual in South Wales. They think that the difference in prevalence of progressive massive fibrosis between the Rhondda Fach and the Durham pits may be due to this difference in age at which heavy dust exposure began in the two areas. As P.M.F. begins on a basis of Category 2 or 3 pneumoconiosis (Cochrane, Fletcher, Gilson, and Hugh-Jones, 1951), the Durham miners of the same age as the Welsh miners had less time in which to develop P.M.F. Cochrane and Gilson conclude that coal-face dusts in Durham have on the average in the last 40 years had the same power of producing simple pneumoconiosis as those in the Rhondda Fach.

The tendency for the number of men in each category of pneumoconiosis to become stable at a certain level may be due to progression from the category below being roughly balanced by withdrawals in the more advanced categories $(3$, and P.M.F.) in which disability from the pneumoconiosis may be more marked. Variations in dustiness in the past, of which there is no record, or a tendency for some older men to transfer to deputy work which takes them intermittently to the face may have a similar result. It is possible also that in some men who have reached one of the simple or complicated categories of 2 or more further accumulation of dust may not be detectable radiologically and the condition may appear to be stationary. The method of assessing the disease radiologically is still 
only relatively accurate and there are many variables. Furthermore, the presence of focal emphysema may explain some of the discrepancies in individual cases by masking the dust foci and giving the appearance of a lower category and this may tend to happen more as the men become older and more emphysematous.

Even after 30 years at the coal face more than a third $(34.8 \%)$ of the radiographs were normal, which does not make it easy to accept wholly a simple time and dust concentration hypothesis for the radiological appearances, although this may explain the regularly increasing categories in the first 20 years of exposure to dust at the coal face.

The proportion of men who withdraw from their well paid coal-face work increases with age, but not with the radiological category of simple pneumoconiosis. This may well be an important point, because in this condition (as in many others) it is only too easy to be overimpressed by the radiograph. But when the appearance is that of progressive massive fibrosis the men tend to give up facework sometimes perhaps because they do not feel well enough, but it must often be because they are advised to do so. Withdrawal from facework is, perhaps, a rough and ready measure of disability, but it is one which is real, not only to the man because it means having to step down in his job with the resulting financial hardship, but also to the industry, because it means a loss of people at the point of production through a preventable industrial disease. A refined physiological test will detect changes in pulmonary function early, but to give industrial information it still has to be linked to a man's ability to work at his ordinary job.

Radiological pneumoconiosis on the scale seen here is important because of its medico-legal implications, for if Category 2 or more is taken as the lowest radiological degree likely to be recognized by a pneumoconiosis medical panel of the Ministry of National Insurance, about $39 \%$ of the faceworkers at these pits would have grounds for an application to such a panel. If men are to receive compensation for $1 \%$ "disability" or "loss of faculty", and if this is regarded as equivalent to radiological pneumoconiosis which is just diagnosable, a greater proportion even than this will have such grounds. Probably only a few of these men have definite symptoms, but the industry could be faced with a serious situation in which a high proportion of key workers were required either to work under approved conditions which might not exist to a sufficient extent, or to change to non-coalgetting work elsewhere in the colliery. This situation is not desirable either from the men's or from the industry's point of view, nor is it necessary. In most cases the men should be allowed to continue at their own work if they are physically capable of doing it, but they should be under medical supervision. The man's own wishes should, of course, also be consulted and the position must be explained to him ; at the same time, if he can be assured that measures to suppress dust are being actively pursued, his anxiety about the dust which he is breathing may to some extent be allayed and his cooperation ensured in suppressing it. Men with progressive massive fibrosis should be allowed to continue at their job if an adequate series of sputum tests, including culture, show that they are free from tubercle bacilli, and close medical supervision is continued, since progression of the lesions in these men probably occurs irrespective of whether they remain in the mine atmosphere or not (Davies and others, 1949).

The fact that half of the faceworkers of middle age show definite radiological signs is of importance, not only because of the potential disability of some of them, but also from the economic and psychological aspects. Practically all these men were regularly at work at the time of the survey and had no disability or were insufficiently disabled to arouse suspicions of occupational disease. Disability in the sense that a change to lighter work had occurred was evident either among the elderly or among those with progressive massive fibrosis. However, it is not easy to distinguish their symptoms from those due to advancing age or bronchitis with emphysema. It may well be that these are the two important variables and that too much attention has been paid in the past to the radiological appearances. If a man who has done facework in this coalfield for 20 years or more has his chest radiographed for any reason, there is more than a $50 \%$ chance that some dust opacities will be found, and this is in accordance with clinical out-patient experience of coalminers in the Newcastle area. This has obviously an important bearing on the diagnosis of chest disease in faceworkers, for the finding may be very misleading if its frequency is underestimated, and in the management of men in whom pneumoconiosis is found incidentally either by mass radiography or hospital investigation for any cause. If breathlessness is the main complaint, other causes such as unrelated lung or heart disease or systemic disease elsewhere must first be excluded, particularly if the disability is out of proportion to the amount of pneumoconiosis.

These results demonstrate how little certification figures may relate to the actual amount of radiological abnormality. Colliery N, which has by far 
the worst record judged by the certification figures, is seen to be only a little worse, in fact, than the others. Many of the men lived in neighbouring urban areas with probably greater risks of tuberculous infection, and it is possible that this is reflected in the high certification figures. Colliery $\mathrm{L}$, on the other hand, is seen to be much worse than certification figures suggest.

With such a high percentage of men showing radiological signs of the disease in the Durham coalfield, policy, treatment, and advice to men who are found to have such changes must be very carefully considered. The disease presents not only as a medical but as an economic problem for which legislation acting through medical boards provides only a partial and, indeed, a rather inflexible solution. It is not always appreciated that the effect of informing a hitherto healthy man that he has "pneumoconiosis" is often harmful. Some other more tactful term which will convey to him that his condition will not necessarily deteriorate is required. Similarly, a man should not be removed from his own job without careful consideration, provided he is physically capable of doing it (McCallum, 1953). But at the same time it must be remembered that pneumoconiosis has medicolegal implications, and that the pneumoconiosis medical panels who see the patients can only operate within their statutory framework.

It is clear that in the recent past faceworkers in the Durham coalfield have been exposed to excessive dustiness in their work and that radiological pneumoconiosis is, as a result, widespread amongst them. Why a substantial proportion of men in these pits remained practically free from radiological abnormality is a question which still requires an answer.

\section{Summary}

Surveys in four Durham coal-mines, where $89 \%$ of the men were radiographed, show that $32 \%$ of them have some evidence of coal-miner's pneumoconiosis and $22 \%$ have radiological Category 2 or more. Only $2 \%$ have progressive massive fibrosis and most of these are early stages.

Films were taken of 5,118 men, and all four collieries showed similar prevalence figures, although they were geographically spread over the coalfield.

Withdrawal from the coal face of men with pneumoconiosis in County Durham is associated with advancing age and particularly with progressive massive fibrosis.

Radiological pneumoconiosis increases in prevalence both with rising age and with length of time spent at facework. Between 26 and 35 years of age nearly $8 \%$ of men have pneumoconiosis of
Category 2 or more, while between 36 and 45 years of age the proportion of men affected rises sharply to $31 \%$. Similarly, after one to 10 years at facework $12 \%$ of men have Category 2 of pneumoconiosis or more, but after 11 to 20 years at the face the proportion rises to $42 \%$.

Length of time at facework is a more important factor in producing the radiological signs of pneumoconiosis than is the length of time spent in the pit as a whole. The critical period at which the effect of facework becomes demonstrable is at about 35 years of age or after about 10 years at facework.

There is a remarkable similarity between the proportion of men at different ages with pneumoconiosis in Durham and South Wales, allowing for a difference in the age at which heavy dust exposure begins.

From the point of view of both the men and the industry as a whole it is better to allow men with pneumoconiosis to continue at their facework under medical supervision, if they are willing to do so, and to persevere with measures to make the work less dusty and so reduce the risk of progression of simple pneumoconiosis or of fresh cases developing.

In County Durham neither past certification figures nor previous estimates from mass miniature surveys show a close relation to the true prevalence as reported here.

Acknowledgments are due to the following :-

The Regional Hospital Board of Region No. 1 and the Durham Mass Miniature Radiography Unit, Dr. D. M. Calvert, Medical Director of the Unit, who took part in the viewing of films, and Mr. W. Davies its secretary ; the National Coal Board, for a grant towards the expenses of the work and for permission to publish, and the National Union of Mineworkers (Durham); also, to Miss I. F. Beck and Miss K. C. Wiggans, and Mr. D. J. Newell and N.rs. D. Weightman, of the Department of Industrial Health.

\section{REFERENCES}

Browne, R. C., Beck, I. F., and McCallum, R. I. (1949). Brit. J. soc. Med., 3, 77 .

Cochrane A L. (1951). In The Application of Scientific Methods to Industrial and Service Medicine, p. 97. Med. Res. Coun. Industrial and Service

H.M.S.O., London.
Fletcher, C. M., Gilson, J. C., and Hugh-Jones, P. (1951). British Journal of Industrial Medicine, 8,53 .

Davies, I., and Fletcher, C. M. (1951). Ibid., 8, 244.

Cox, J. G., and Jarman, T. F. (1952). Brit. med. J., 2, 843

-, and Gilson, J. C. (1953). Unpublished communication.

Davies, I., Fletcher, C. M., Mann, K. J., and Stewart, A. (1949) Proceedings of the Ninth International Congress on Industria Medicine, 1948. London, p. 773. Wright, Bristol.

Fletcher, C. M. (1953). Third International Conference of Experts on Pneumoconiosis, I.L.O., Sydney, 1950. Vol. 2, p. 159. International Labour Office, Geneva.

, Mann, K. J., Davies, I., Cochrane, A. L., Gilson, J. C., and Hugh-Jones, P. (1949)., J. Fac. Radiol., i, 40.

Heppleston, A. G.'(1951). Arch. industr. Hyg., 4, 270.

International Labour Office (1953). Third International Conference

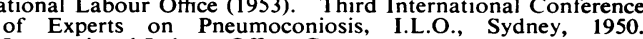
of Experts on Pneumoconiosis, I.L.O., Sydney, 1950.
International Labour Office, Geneva.

International Labour Office, Geneva.
McCallum, R. I. (1952). British Journal of Industrial Medicine, 9, 99.

McCallum, R. T. (1952). British Journal of Industric

Newell, D. J., and McCallum, R. I. (1954). J. Fac. Radiol. 6, 67. 